\title{
The Perceptions Of Students On The Use Of Social Networking Systems As A Teaching Tool In ODL Institutions
}

Johannes A. Wiid, University of South Africa (UNISA), South Africa Michael C. Cant, University of South Africa (UNISA), South Africa

Safura M. Kallier, University of South Africa (UNISA), South Africa

\begin{abstract}
Technology has provided many new methods of communicating and has changed the way in which students interact with each other. This had an impact on the way in which students of today interact with their learning environment as well. Educational institutions have started to make use of technology to better their interaction with students and the level of education that they provide. Open and Distance Leaning (ODL) institutions have made use of this technology to provide a better learning environment and service to the students. This article aims to determine the level of acceptance of e-learning systems and technology in ODL institutions.
\end{abstract}

Keywords: Education; ODL Institutions; Technology; TAM; E-Learning; Students

\section{INTRODUCTION}

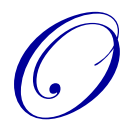

ver the past few years, technology has modernised the way in which we live, the way we do business, the methods we use to communicate with each other and the way in which we learn. The development of new technology and interactive communication tools, such as text messaging, instant messaging and social networking sites, has also impacted in the field of education and has changed the way in which students interact with each other and their environment (Educause, 2009:13). Technology influenced the interaction between students and educators as well as the methods available for students to gain access to learning content (Alsanaa, 2012:47-50).

These changes in technology have influenced Open and Distance Learning (ODL) institutions, in particular, and the methods used by these institutions to deliver courses to students (Ruhe \& Zumbo, 2009:2). ODL institutions provide students with the ability to study at a convenient time and place (Ruhe \& Zumbo, 2009:2). It also allows students to overcome problems such as physical distance, time and scheduling issues, limited space for certain courses, and cost (Mishra, 2010).

ODL institutions have used technology to enhance the educational process by making use of the various methods of delivering content such as video teleconferencing, CD-ROM's and blended learning, which uses both technology and human interface (Ruhe \& Zumbo, 2009:2). The growth of technology and the use of the internet have also resulted in the use of online and e-learning systems in delivering highly interactive and widely accessible learning opportunities (Venter, Van Rensburg \& Davis, 2012: 83-198). E- Learning refers to learning that is conducted through the use of technology and includes the use of online and offline technological tools such as computers and the internet (Alsanaa, 2012:47-50). It makes use of technology to provide ODL institutions with the programmes and processes that provide students with online access and relevant learning content (Park, 2009:150162).

This study is a follow up on a similar study conducted by the authors entitled: "Open Distance Learning Students' Perception Of The Use Of Social Media Networking Systems As An Educational Tool”, published in the International Business \& Economics Research Journal (Wiid, Cant \& Nell. 2013 12(8):867-882). As the general theme is very similar to this article some overlap in the research methodology discussion will occur. 
E-learning places emphasis on greater interaction from the students as they are given assignments and activities that are submitted electronically, and they are able to participate in online group discussions and are provided with feedback electronically (Addah, Kpebu \& Kwapong, 2012:51-62). It also provides students with the ability to access the relevant content from anywhere, the ability to gain assistance from lecturers and e-tutors if necessary and the ability to share their experiences with others (Ruhe \& Zumbo, 2009:4). In this study, e-learning is considered to be the use of various technology and communication mediums to deliver relevant information to students and to facilitate student interaction in ODL institutions.

E-learning consists of various tools, such as computers, internet, telephone, videos, radio and mobile phones, to support the learning process. Communication mediums, such as social networking sites (SNS), can also be adopted as part of e-learning programmes for ODL institutions and can contribute to the interaction and communication with students. Social networking sites are websites that provide a platform for individuals to create profiles, form relationships with other users, comment and partake in discussions with others (Webopedia, n.d.). These sites can provide an opportunity for ODL institutions to enhance the learning experience and student interaction (Sewry \& Schlenkrich, 2012:12-24). A study conducted by Hoffman (2009) suggests that SNS tools can offer considerable advantages for ODL institutions. The study indicated that some of the positive attributes of using SNS's include student engagement, motivation and interaction from the student (Hoffman, 2009:92-100).

Self-serving technologies (SST) refers to the systems used by a business that make it possible for individuals to make purchases or use a service on their own without any interaction from the business (Makarem, Mudambi \& Podoshen, 2009:135). SST's allow individuals to perform services by themselves in a manner that is convenient for them and includes ATM's, online payment options, mobile services and online booking options (Winifred, 2013:1). ODL institutions have made use of SST's, such as online web services, that provide students with relevant information regarding their studies, online payment options, study materials such as study guides and study notes, online access to library and other resources that they might need. The adoption of SST's in ODL institutions provide students with learning that is flexible, convenient and cost effective (Katz, 2012).

SST and communication tools, such as SNS, can play a vital role in delivering enhanced and interactive education in ODL institutions. Together with technology, e-learning can close the distance gap between students and facilitators (Addah, Kpebu \& Kwapong, 2012:51-62). This, however, can only be done if facilitators and students fully adopt and make use of the e-learning tools available to them. It is thus important for institutions implementing e-learning systems to consider the involvement, attitude and acceptance of these systems by students and facilitators (Al-Adwan, Al-Adwan \& Smedly, 2013:4-18).

User acceptance of technology has been of interest to researchers over the years and many models have been developed and used to explain and predict the use of technology. The Technology Acceptance Model, however, is the most common and widely accepted model used to explain the acceptance and use of technology (Addah, Kpebu \& Kwapong, 2012:51-62). In this research, TAM will be used to explain the acceptance of technology and social networking systems in ODL institutions among students and lecturers.

\section{THEORETICAL FRAMEWORK}

The Technology Acceptance Model (TAM) was developed by Davis in 1989 with the purpose of providing an explanation as to why a user accepts or rejects new technology (Park, 2009:150-162). This model explains that there are certain factors that will influence the use of technology. Some of these refer to the individual's behavioural intentions, attitude, perceived usefulness of the system and the perceived ease of use of the system (Venter, Van Rensburg \& Davis, 2012:183-198). The behavioural intension of the individual is influenced by their attitude towards technology and using the new system (Venter, Van Rensburg \& Davis, 2012:183-198). There are two determinants that regulate the attitude of the individual; these determinants are perceived usefulness and perceived ease of use (Venter, Van Rensburg \& Davis, 2012:183-198).

Figure 1 depicts the original TAM (Davis, Bagozzi \& Warshaw, 1989:982-1003). 


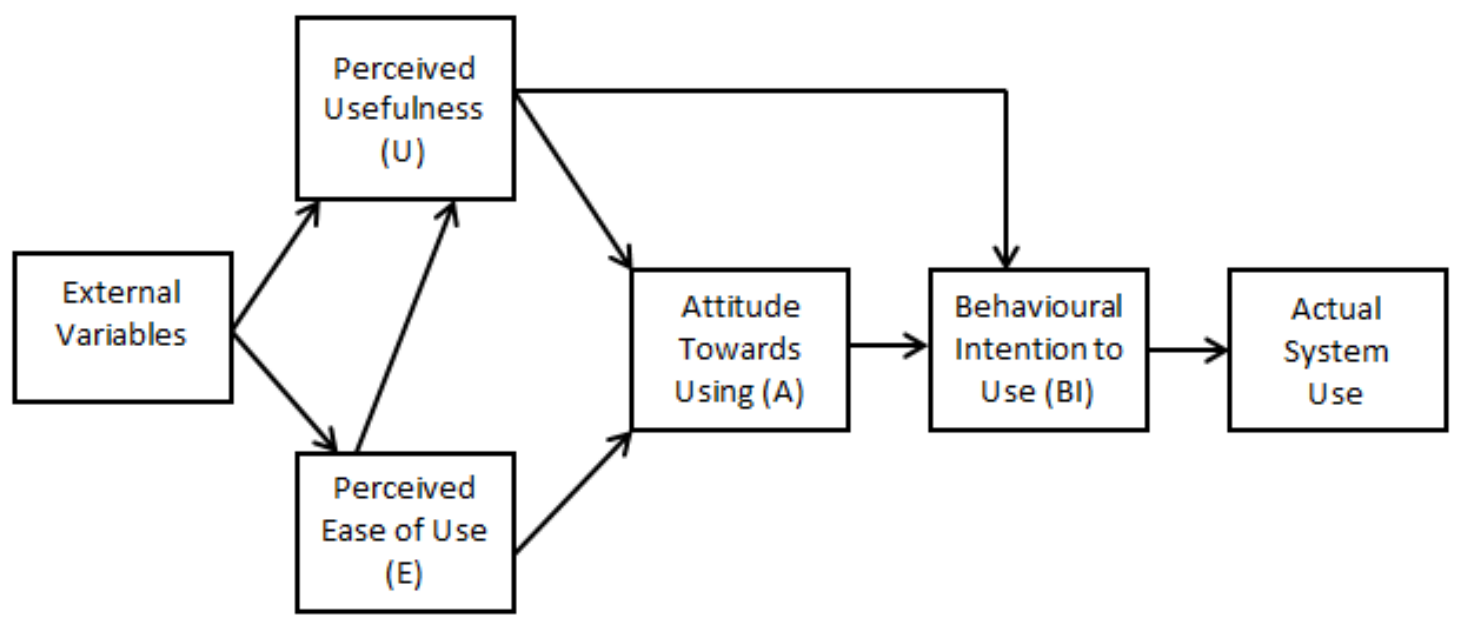

Figure 1: Technology Acceptance Model

Perceived usefulness refers to the degree in which the individual believes that technology will enhance their work performance (Alsanaa, 2012:47-50). Individuals will use a system if they believe that it will help them do their jobs more reliably and accurately (Chuttur, 2009:2). The perceived ease of use refers to how effortless the individual perceives using the technology will be (Alsanaa, 2012:47-50). This variable determines how comfortable an individual is with the technology and whether the individual thinks the system will be easy or difficult to understand (Mangin, Bourgault, León \& Guerrero, 2012:14).

The perceived usefulness and perceived ease of use influences the individual's attitude towards using new technology (Chuttur, 2009:2). The individual's attitude towards using the new technology refers to their positive or negative feelings towards the new technology (Mangin, et al., 2012:14). The individual's attitude towards the new technology influences the behavioural intention to use the new technology and the actual use of the new technology (Wong, Osman, Goh \& Rahmat, 2013:93). The behavioural intention to use refers to the individual's intention to adopt the new technology or reject it, which influences the individual's actual use of the new technology (Mangin, et al., 2012:14).

External variables, such as culture and beliefs, can also have an effect on an individual's intention and the actual use by influencing the perceived usefulness and perceived ease of use (Park, 2009:150-162).

TAM has been used for a number of studies to investigate the acceptance of information technology such as the World Wide Web, mobile banking and multimedia (Park, 2009:150-162). Numerous studies using TAM have also been done with regard to e-learning and the acceptance and adoption of technology and e-learning systems (Park, 2009:50-162). A study conducted by Al-Adwan et al. (2013) indicated that TAM is useful in understanding individuals' intentions to use e-learning. The TAM model also proved to be successful in a study conducted by Edmunds, Thorpe and Conole (2012) in understanding the use of technology by students for their studies, for work and social activities.

\section{Students And The Use Of Technology}

Today's students have grown up with technology and the internet at their disposal (Gupta \& Soni, 2012:481). They have always been connected to some technology or some media and are naturally capable of making use of various technologies (Oblinger \& Oblinger, 2005). A survey conducted by CourseSmart showed that, on average, students use up to three technological devices on a daily basis (Sohn, 2012). Forty percent of the respondents surveyed indicated that they use some form of digital technology every ten minutes (Sohn, 2012). Another survey conducted shows that 87 percent of undergraduate college students own a laptop computer and that 95 percent of 18 - 33 year olds make use of the internet (Junco, 2013:75). 
In recent years, the different types of technological devices used by the students and the ways in which students use technology and the internet have become of interest. Gosper, Malfroy, McKenzie and Rankine (2011) found that the most used technologies among students are internet search engines, text messages, email, mobile phones for voice calls and SNS. Kvavik (2014) conducted a survey among 13 university institutions in the United States which revealed that 99.5 percent of students use their computers for writing word documents and e-mails, followed by using the internet for pleasure and then for classroom activities. A study conducted by Bashir, Mahmood and Shafique on the internet usage among university students in Pakistan showed that 63 percent of the students used the internet for preparing their class assignments, 32 percent of students used it for communication purposes, 24 percent used it for entertainment, and only 17 percent used it to prepare for their exams.

Figure 2 shows the percentage of various devices owned by students.

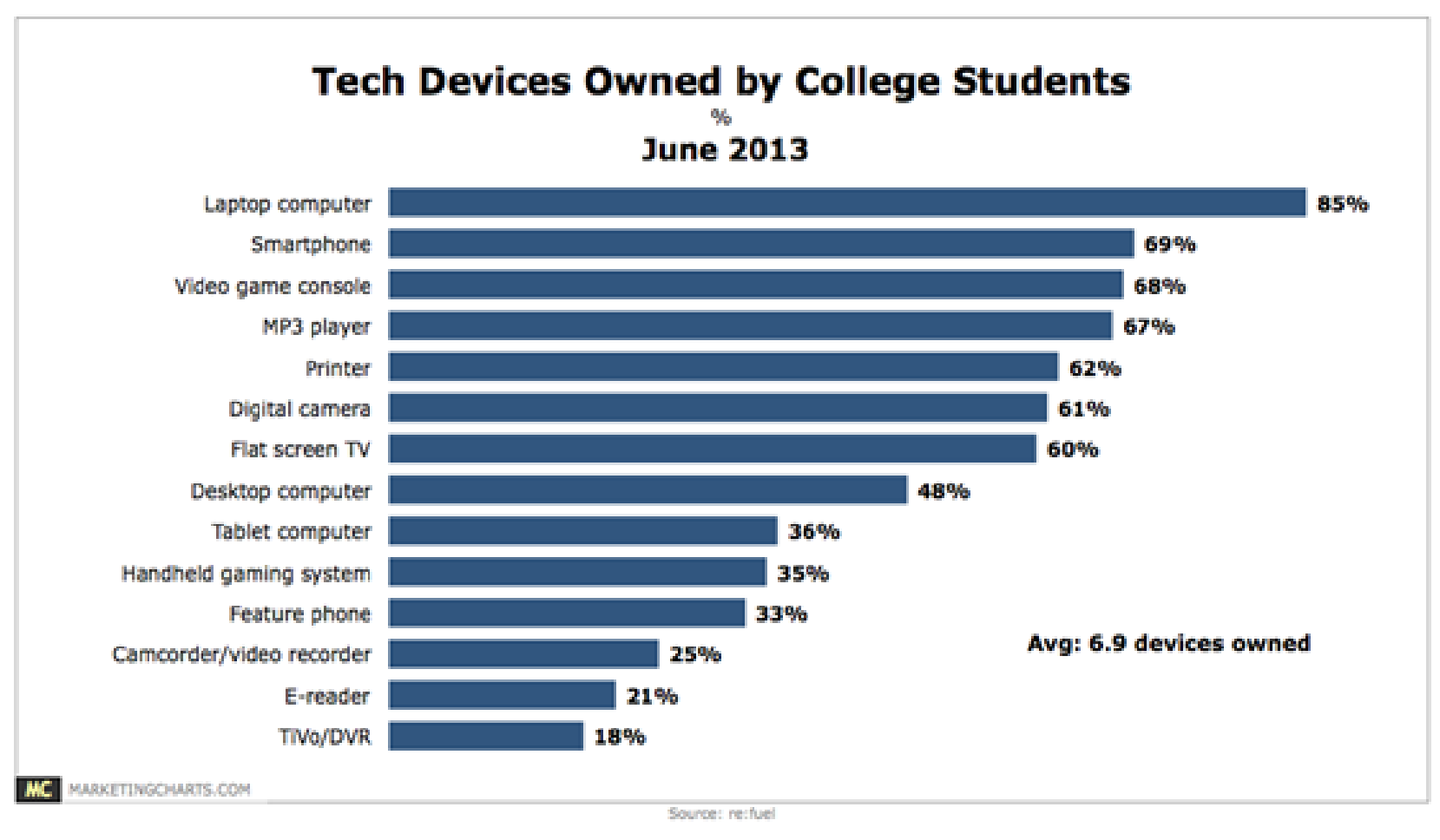

Source: Marketing Charts. 2013

Figure 2: Technological Devices Owned By Students

Students are making use of their laptops, tablets and even smart phones in the classroom to take notes, do research and download class notes and textbooks (Re:fuel, 2013). Re:fuel's annual College Explorer survey in 2013 revealed that 33 percent of students use their tablets to take notes in class and 37 percent use their tablets to read electronic books. The survey also showed that 13 percent of students use their smart phones to take notes in class (Re:fuel, 2013).

University students have become accustomed to technology in their everyday lives and expect this technology to be incorporated into the teaching and learning of university institutions (Lai, 2011:1263). The Undergraduate Technology Survey conducted by Educause Centre for applied Research (2012) indicated that 64 percent of students believe that the use of technology in the classroom uplifts the level of teaching (Dahlstrom \& EDUCAUSE, 2012:9). The study also revealed that students believe that technology is important to their success in achieving their educational goals (Dahlstrom \& EDUCAUSE, 2012:31). Students believe that the use of technology in the classroom improves their work efficiency and their learning ability (Kvavik, 2014). They perceive the use of technology to be more convenient and believe that it saves time and influences the way in which students behave (Kvavik, 2014). 
Many universities and higher education institutions have started incorporating information and communication technologies to better their students' learning environment. The ETH Zurich University in Switzerland released an application that allows staff and students access to the university's calendar events, news and map of the campus. It also allows the user to access contact information of their staff members (QS Top Universities, 2014). The Virginia Commonwealth University in the United States makes use of video conferencing through Skype, Google Hangouts and Adobe Connect to facilitate their language courses (Hernandez, 2014). Students who are doing, for example, a Spanish course at the university are paired with students who are doing an English course in another country. The students are then able to teach each other the languages. In Canada, universities in Montreal have launched UniYu, which is a student online network used to share class notes, advice from other students and keep in touch with other students (QS Top Universities, 2014). From the above examples, it becomes evident that technology can assist in making education more interactive and collaborative for students.

Students of today want a flexible learning environment that incorporates various technologies and that can adapt to the students' needs (McLaughlin \& Faulkner, 2012:1). With the use of technology, ODL institutions have the ability to provide students with this type of flexible education.

\section{RESEARCH OBJECTIVE}

The purpose of this study is to determine the perceptions of students on social network systems and their use of it. Within the context of an ODL institution, this study aims to:

- $\quad$ Explore the constructs of the TAM model with regard to the student's view

- $\quad$ Explore the proposed constructs using the technology acceptance model TAM

The Technology Acceptance Model (TAM) is the most common and widely accepted model used to explain the acceptance and use of technology (Addah, Kpebu \& Kwapong, 2012:51-62).

According to Mazhar (2006), the main goal of TAM is "to provide an explanation of the determinants of computer acceptance that is general and capable of explaining user behaviour across a broad range of end-user computing technologies and user populations, while at the same time being both parsimonious and theoretically justified". TAM indicates that if a specific technology is perceived as being useful by the user, they will believe in a positive user- performance relationship (Cant, Wiid \& Nell, 2013:6). As effort is a limited resource, a user is most likely to accept the new technology when they perceive it as being easier to use than older technology or a different application.

As an end result, educational technology that has a high level of Perceived Usefulness (PU) and Perceived Ease of Use (PEOU) is probably going to encourage a positive perception. The relationship that exists between PU and PEOU is that PU arbitrates the effect of PEOU on both attitude and future use. This simply means that while PU has a direct impact on attitude and use, PEOU has an indirect influence on attitude and use through PU. The following hypotheses are therefore being stated:

$\mathbf{H}_{1} \quad$ 'Ease of use' will significantly influence users' perceived 'usefulness' of social network systems.

$\mathbf{H}_{2}$ There is a positive association between 'usefulness' and 'attitude and intention' to adopt social network systems.

$\mathbf{H}_{3}$ There is a positive association between 'ease of use' and 'attitude and intention' to adopt social network systems.

The methods that were used in order to obtain the relevant data are discussed in the next section followed by the empirical findings and a discussion of the findings. 


\section{RESEARCH METHODOLOGY}

To determine the acceptance of social media as a lecturing tool, a questionnaire was developed which mostly incorporated questions that are of a quantitative nature. A total of 221 correctly completed questionnaires were obtained.

Table 1 presents the demographic profile of the respondent group. The majority of students ( 29.80 percent) were between 18 and 24 years of age. The gender split for the respondent group is dominated by females, with 63 percent of the students being female.

Table 1: Demographic Profile

\begin{tabular}{|l|c|c|}
\hline Age Group & \% Of Total & N \\
\hline $18-24$ & $29.80 \%$ & 59 \\
\hline $25-29$ & $25.25 \%$ & 50 \\
\hline $30-34$ & $17.68 \%$ & 35 \\
\hline $35-39$ & $15.66 \%$ & 31 \\
\hline $40+$ & $11.62 \%$ & 23 \\
\hline Gender & & \\
\hline Male & $37.00 \%$ & 74 \\
\hline Female & $63.00 \%$ & 126 \\
\hline
\end{tabular}

\section{RESEARCH FINDINGS}

To determine the student's acceptance of social media networking systems as a lecturing tool, respondents were asked to rate 20 statements on a seven-point Likert scale ( 1 being "Strongly disagree" and 7 being "Strongly agree"). The 20 statements are structured as sub-constructs according to the technology acceptance model (TAM):

- $\quad$ 'Perceived ease of use': statements 1 to 5

- $\quad$ 'Perceived usefulness': statements 6 to 10

- 'Attitude towards using': statements 11 to 15

- $\quad$ 'Intention to use': statements 16 to 20

\section{Construct Validity TAM Students}

An exploratory factor analysis was performed to examine construct validity of the measures adopted in this study. Principal factor analysis with Varimax rotation was conducted to assess the underlying structure for the twenty items of the TAM questionnaire. Three factors were found, even when the items were designed to index four constructs. The three factors/constructs are: 1) a combination of 'attitude toward using and intention to use', which becomes one combined construct instead of the original two; 2) 'perceived ease of use'; and 3) 'perceived usefulness'. After rotation, the first factor accounted for 24.72 percent of the variance, the second factor accounted for 21.89 percent, and the third factor accounted for 18.54 percent. In Table 2, the items and factor loadings for the rotated factors, with loadings less than 0.40 omitted to improve clarity, are displayed. 
Table 2: Factor Loadings For The Rotated Factors

\begin{tabular}{|c|c|c|c|}
\hline Scale Item (Statement No.) & Factor 1 & Factor 2 & Factor 3 \\
\hline $\mathbf{1}$ & & 0.84 & \\
\hline $\mathbf{3}$ & & 0.80 & \\
\hline $\mathbf{4}$ & 0.43 & 0.65 & 0.76 \\
\hline $\mathbf{5}$ & & & 0.80 \\
\hline $\mathbf{6}$ & & & 0.81 \\
\hline $\mathbf{8}$ & 0.44 & 0.44 & 0.47 \\
\hline $\mathbf{9}$ & & & 0.63 \\
\hline $\mathbf{1 0}$ & 0.53 & & \\
\hline $\mathbf{1 2}$ & 0.40 & & \\
\hline $\mathbf{1 3}$ & 0.39 & & \\
\hline $\mathbf{1 4}$ & 0.63 & & \\
\hline $\mathbf{1 5}$ & 0.62 & & \\
\hline $\mathbf{1 6}$ & 0.40 & & 0.50 \\
\hline $\mathbf{1 7}$ & 0.65 & & \\
\hline $\mathbf{1 8}$ & 0.72 & & \\
\hline $\mathbf{2 0}$ & 0.68 & & \\
\hline \% of vamulative variance & 0.76 & & 0.43 \\
\hline explained & 0.56 & & \\
\hline
\end{tabular}

Principal components were measured by making use of Varimax rotation and Kaiser normalisation; $\mathrm{N}=$ 221. Factor 1 = 'Attitude toward using and Intention to use', Factor 2 = 'Perceived ease of use', and Factor 3= 'Perceived usefulness'. Most factor loadings were 0.6 or above, showing good convergent validity (Chesney, 2006). However, a lot of cross-loadings were experienced across all three factors that could mean students perceive the constructs to be more as a unit than separate concepts.

\section{Measures}

Reliability refers to the degree to which an instrument measures the same way each time it is used under the same condition with the same subjects; that is, the consistency of the measurement (Cant, Wiid \& Nell, 2013:12). A Cronbach's alpha value above 0.8 has a good reliability, a value between 0.6 and 0.8 has an acceptable reliability, and a value below 0.6 has an unacceptable reliability. Hair, Anderson, Tatham \& Black (1998) recommended that Cronbach alpha values from 0.6 to 0.7 were deemed the lower limit of acceptability.

The Cronbach's alpha for the three sub-constructs all yielded high Cronbach's alpha values $(>=0.80)$ which is considered very good (Nunnally, 1978). Table 3 represents the Cronbach's alpha values, mean scores, and standard deviation of each of the sub-constructs. Hence, the results demonstrate that the sub-constructs in the questionnaire is a reliable measurement instrument.

Table 3: Cronbach's Alpha Values, Mean Scores, And Standard Deviation Of Each Of The Sub-Constructs

\begin{tabular}{|l|c|c|c|}
\hline \multicolumn{1}{|c|}{ Construct/Scale } & Cronbach's Alpha & Mean & Std. Dev. \\
\hline $\begin{array}{l}\text { Attitude towards using and Intention to use } \\
(9,12,13,14,15,16,17,18,19,20)\end{array}$ & 0.93 & 4.55 & 1.70 \\
\hline Perceived ease of use $(1,2,3,4,5)$ & 0.92 & 4.98 & 1.80 \\
\hline Perceived usefulness $(6,7,8,10)$ & 0.91 & 4.44 & 1.85 \\
\hline
\end{tabular}

'Perceived ease of use' was considered most important with a mean of 4.98, while 'Perceived usefulness' was least important with a mean of 4.44 . The means were closely distributed, indicating a general agreement on the importance of all the sub-constructs, but not strong. The standard deviations are fairly high, indicating variation in agreement among sub-constructs. 


\section{RESULTS AND ANALYSIS}

The research model shown in Figure 3 was tested using the Statistical Analysis System (SAS JMP) software.

To identify the relationship between the chosen constructs, regression analysis is performed on the constructs, keeping in mind the flow structure of the TAM model. This was achieved by performing three separate regression analyses.

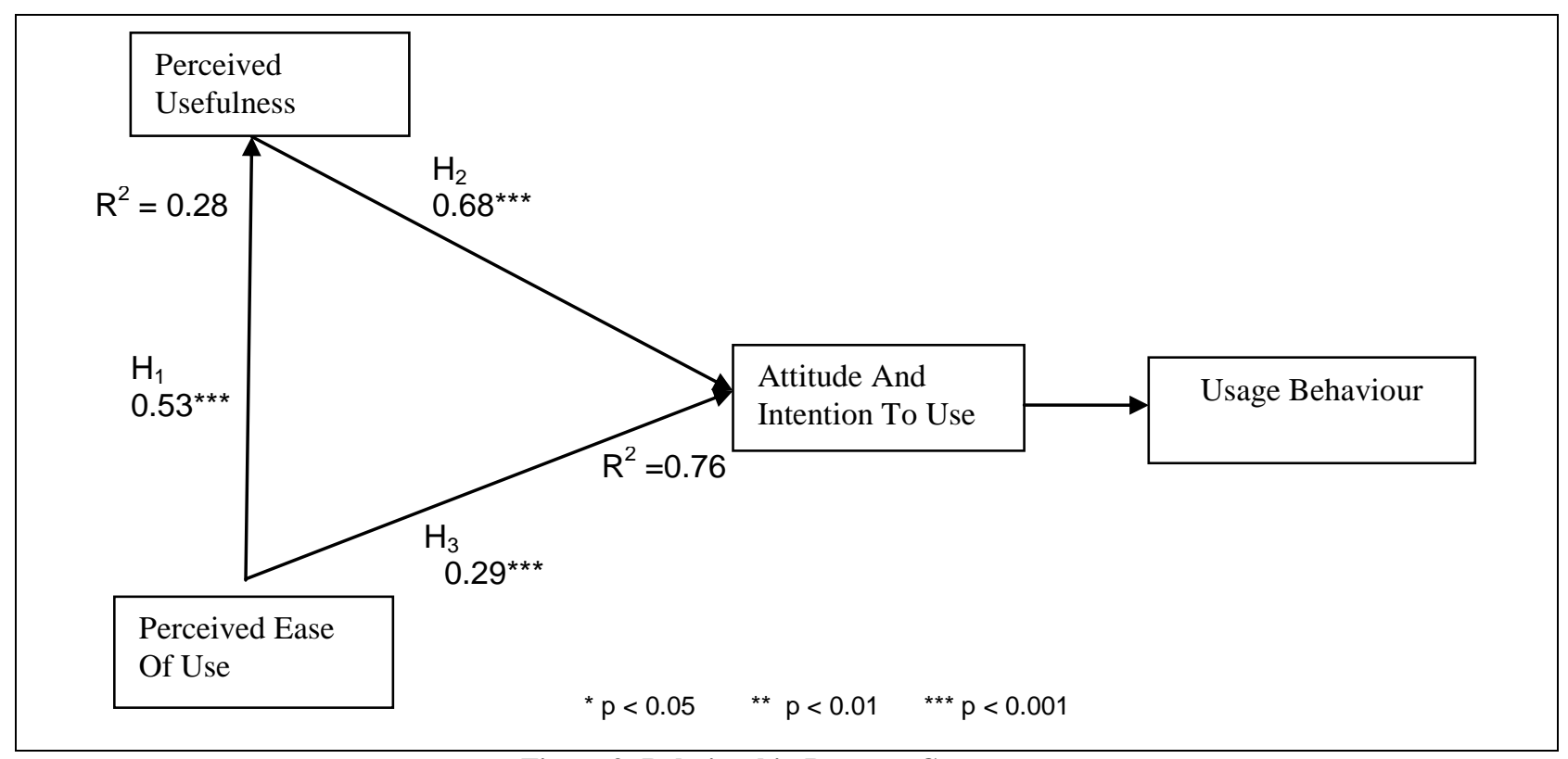

Figure 3: Relationship Between Constructs

The first regression analysis tested the relationship between single predictor ease of use and usefulness as the dependent variable. From the analysis, a significant model emerged $\left(\mathrm{F}_{1,160} \approx 63.32 ; \mathrm{p}<0.0001\right)$ with a $\mathrm{R}$ Square of 0.28 (see Figure 3). The coefficient between ease of use and usefulness was also found significant $(\beta=.53, \mathrm{p}<$ $.0001)$.

Table 4: Regression Analysis - Relationship Between Single Predictor Ease Of Use And Usefulness As Dependent Variable Regression: $\left(\mathrm{R}^{2}=0.28 ; \mathrm{F}_{1,160} \approx 63.32 ; \mathrm{p}<0.0001\right)$

\begin{tabular}{|l|c|c|c|c|c|}
\hline $\begin{array}{c}\text { Dependent } \\
\text { Variable }\end{array}$ & $\begin{array}{c}\text { Independent } \\
\text { Variable }\end{array}$ & $\begin{array}{c}\text { Std. Beta } \\
\text { Coefficient }\end{array}$ & t-Value & p-Value & Significance \\
\hline Usefulness & Ease of use & 0.53 & 7.96 & $\mathrm{p}<0.0001$ & Highly significant \\
\hline
\end{tabular}

The second regression analysis tested the relationship between predictors (i.e., usefulness and ease of use) and attitude/intention as the dependent variable. From the analysis, a significant model emerged $\left(\mathrm{F}_{2,160} \approx 251.47\right.$; $\mathrm{p}<0.0001)$ with the adjusted $\mathrm{R}$ Square of 0.76 . The impact of both variables were significant: perceived usefulness $(\beta=0.68, \mathrm{p}<.0001)$ and ease of use $(\beta=0.29, \mathrm{p}<.0001)$.

Table 5: Regression Analysis - Relationship Between Predictors (i.e., Usefulness And Ease Of Use) And Attitude/Intention As Dependent Variable Regression: $\left(\mathrm{R}^{2}=0.76 ; \mathrm{F}_{2,160} \approx 251.47 ; \mathrm{p}<0.0001\right)$

\begin{tabular}{|c|l|c|c|c|c|}
\hline \multicolumn{2}{|l|}{ Regression: $\left(\mathrm{R}^{2}=0.76 ; \mathrm{F}_{2,160} \approx 251.47 ; \mathrm{p}<0.0001\right)$} & p-value & Significance \\
\hline $\begin{array}{c}\text { Dependent } \\
\text { Variable }\end{array}$ & $\begin{array}{c}\text { Independent } \\
\text { Variable }\end{array}$ & $\begin{array}{c}\text { Std. Beta } \\
\text { Coefficient }\end{array}$ & t-value & $\mathrm{p}<0.0001$ & Highly significant \\
\hline \multirow{2}{*}{ Attitude/Intention } & Usefulness & 0.68 & 14.79 & $\mathrm{p}<0.0001$ & Highly significant \\
\cline { 2 - 7 } & Ease of use & 0.29 & 6.36 &
\end{tabular}




\section{CONCLUSION}

The Technology Acceptance Model (TAM) is an information system theory that consists of all the network communication channels used within an organisation and that demonstrates how specific technology is accepted and used by users (Davis, 1993:475). The model indicates that when users are confronted with a new technology, various factors influence their decision about how and when they will use this specific technology (Mazhar, 2006). Davis, Bagozzi and Warshaw (1989:985) indicated that there are three constructs that explain user motivation, such as 'Perceived ease of use', 'Perceived usefulness', and 'Attitude toward using the system and Intention to use'. The first construct - 'Perceived usefulness' - is defined by Davis (1993:477) as “... the degree to which an individual believes that using a particular system would enhance his or her job performance". The second construct 'Perceived ease of use' - is defined as "... the degree to which an individual believes that using a particular system would be free from effort" (Davis, 1993:477). The third construct - 'Attitude towards using the system and Intention to use' - is defined as "... the degree of evaluative affect that an individual associates with using the target the target system in his or her job" (Davis, 1993:477).

Revised statements borrowed from the TAM model, as depicted in Figure 1, covering the four constructs perceived ease of use (PEOU), perceived usefulness (PU), attitude towards using (A) and intention to use (I) - were included in the questionnaire. Factor analysis was performed on the statements and two constructs attitude toward using (A) and intention to use (I) emerged as a single construct. The inference can be drawn that social media is an integral part of their everyday life and therefore there is no distinction to be drawn between attitude and intention when it comes to the use of social media as a learning tool. This supports the original TAM that motivation can be explained by three constructs - 'Perceived ease of use', 'Perceived usefulness', and 'Attitude toward using the system and Intention to use'.

The proposed positive linkage between perceived usefulness and ease of use from the first hypotheses (H1) is significant. It is clear from the empirical analysis that usefulness plays a significant role in predicting attitude/intention toward social network systems (H2). Ease of use has also been found to be a significant factor in determining attitude/intention toward social network systems confirming the second hypothesis (H3). Findings presented in the Table 5 suggest that usefulness $(\beta=.68)$, in comparison to ease of use $(\beta=.29)$, has more impact on attitude/intention toward social network systems.

The study has also looked at ease of use as a predictor, taking usefulness as a dependent variable.

Social network systems are an integral part of everyday life and students are motivated to use them. It is therefore recommended that institutions of higher learning put mechanisms in place to support the use of social networking systems by students. It is further recommended that higher learning institutions develop social networkfriendly programmes and material in order to enhance the students' learning experiences.

\section{AUTHOR INFORMATION}

Professor Johannes A. Wiid is a Professor in the Department of Marketing and Retail Management at the University of South Africa (Unisa). He has published numerous articles in refereed journals and is the editor and author of various marketing-related textbooks which are widely prescribed at universities in South Africa. He holds a DCom in Marketing from the University of Johannesburg. E-mail:jwiid@unisa.ac.za.

Professor Michael C. Cant is the head of the Department of Marketing and Retail Management at the University of South Africa (Unisa). He has published over 50 accredited articles in refereed journals and is the editor and author of numerous marketing textbooks which are widely prescribed at universities in South Africa. He has presented papers at more than 45 international conferences all over the world and is a well-respected marketing and retail scholar. He holds a DCom in Marketing from the University of South Africa. Email: cantmc@unisa.ac.za.

Ms. Safura M. Kallier is a lecturer in the Department of Marketing and Retail Management at the University of South Africa. She graduated from the University of Pretoria with a BCom (Hons) in Marketing Management and is currently undertaking her Master's degree in Business Management at Unisa. Her areas of interest include branding, e-marketing and retail. Email: kallism@unisa.ac.za. 


\section{REFERENCES}

1. Addah, K., Kpebu, D., \& Kwapong, O. A. T. F. (2012). Promoting e-learning in distance education in an African country. E-Learning - Long-Distance and Lifelong Perspectives, 1(3), 51-62. Retrieved from: http://cdn.intechopen.com/pdfs/31953/InTechPromoting_e_learning_in_distance_education_programs_in_an_african_country.pdf.

2. Al-Adwan, A., Al-Adwan, A., \& Smedly, J. (2013). Exploring student's acceptance of e-learning using Technology Acceptance Model in Jordanian universities. International Journal of Education and Development using Information and Communication Technology (IJEDICT), 9(2), 4-18. Retrieved from: http://ijedict.dec.uwi.edu/viewarticle.php?id=1617.

3. Alsanaa, B. (2012). Students' acceptance of incorporating emerging communication technologies in higher education in Kuwait. World Academy of Science, Engineering and Technology, 1(64), 47-50. Retrieved from: http://www.waset.org/journals/waset/v64/v64-10.pdf.

4. Bashir, S., Mahmood, K., \& Shafique, F. (not dated). Internet use among university students: a survey in University of the Punjab, Lahore, Pakistan. Retrieved:

http://www.academia.edu/1191010/Internet_use_among_university_students_A_survey_in_University_of_t he_Punjab_Lahore_Pakistan.

5. Cant, M. C., Wiid, J. A., \& Nell, C. (2013). The perceptions of ODL students towards the use of social media networking systems. The Asian Conference on Technology in the Classroom 2013 Official Conference Proceedings 2013, 1-17. Retrieved from: http://www.iafor.org/offprints/actc2013offprints/ACTC2013_Offprint_0018.pdf.

6. Chesney, T. (2006). An Acceptance model for useful and fun information systems. An Interdisciplinary Journal of Humans in ICT Environments, 2(2), 225-235. Retrieved from: http://www.humantechnology.jyu.fi/articles/volume2/2006/chesney.pdf.

7. Chuttur, M. Y. (2009). Overview of the Technology Acceptance Model: origins, developments and future directions. Sprouts: Working Papers on Information Systems, 9(37), 1-22. Retrieved from: http://sprouts.aisnet.org/785/1/TAMReview.pdf.

8. Davis, D. F. (1993). User acceptance of information technology: system characteristics, user perceptions and behavioural impacts. International Journal of Man-Machine studies, 1(38), 475-487. Retrieved from: http://deepblue.lib.umich.edu/bitstream/handle/2027.42/30954/0000626.pdf.

9. Davis, D. F., Bagozzi, R. P., \& Warshaw, P. R. (1989). User Acceptance of Computer Technology: A Comparison of Two Theoretical Models. Management Science, 35(8), 982-1003. Retrieved from: http://www.jstor.org/stable/2632151.

10. Dahlstrom, E. (2012). ECAR study of undergraduate students and information technology, 2012 (Research Report). Louisville: EDUCAUSE Center for Applied Research. Retrieved from: http://net.educause.edu/ir/library/pdf/ERS1208/ERS1208.pdf.

11. Edmunds, R., Thorpe, M., \& Conole, G. (2012). Student attitudes towards and use of ICT in course study, work and social activity: a technology acceptance model approach. British Journal of Educational Technology, 43(1), 71-84. Retrieved from: http://onlinelibrary.wiley.com/doi/10.1111/j.14678535.2010.01142.x/pdf.

12. Educause. (2009). Students and information technology. Educause Centre for Applied Research, 1(6), 1121. Retrieved from: http://net.educause.edu/ir/library/pdf/ers0906/rs/ers09061.pdf.

13. Gupta, P., \& Soni, P. (2012). E-Learning through cloud computing: shaping the future of learning for learner of tomorrow. International Conference on Information Technology and Management. Retrieved from: http://link.springer.com/chapter/10.1007/978-3-642-34910-2_56\#page-2.

14. Gosper, M., Malfroy, J., McKenzie, J., \& Rankine, L. (2011). Students' engagement with technologies: implications for university practice. Proceedings ascilite 2011 Hobart :concise paper. Retrieved from: http://www.ascilite.org.au/conferences/hobart11/downloads/papers/Gosper-concise.pdf.

15. Hair, J. F., Anderson, R. E., Tatham, R. L., \& Black, W. C. (1998). Multivariate Data Analysis. 5 th Ed. Upper Saddle River, NJ: Prentice Hall.

16. Hernandez, D. P. (2014). Technology Provides Foreign-Language Immersion at a Distance. Retrieved from: http://chronicle.com/article/Technology-Provides/146369/.

17. Hoffman, S. E. (2009). Evaluating social networking tools for distance learning. Technologies, Colleges and Community (TCC) 2009 Proceedings, 92-100. Retrieved from: 
http://etec.hawaii.edu/proceedings/2009/hoffman.pdf.

18. Junco, R. (2013). iSpy: seeing what students really do online. Leaning, Media and technology. Retrieved from: http://www.tandfonline.com/doi/pdf/10.1080/17439884.2013.771782.

19. Katz, J. M. (2012). Using Self-Service Lanes to Enhance Higher Education. Retrieved from: http://www.katz.pitt.edu/deanblog/?p=54.

20. Kvavik, R. B. (2014). Convenience, communications and control: How students use technology. EDUCAUSE Center for Analysis and Research and University of Minnesota, Twin Cities. Retrieved from: $\mathrm{http}: / / \mathrm{www}$.educause.edu/research-and-publications/books/educating-net-generation/conveniencecommunications-and-control-how-students-use-technology.

21. Lai, K. (2011). Digital technology and the culture of teaching and learning in higher education. Australasian Journal of Education and Technology, 27(8), 1263-1257. Retrieved from: http://www.ascilite.org.au/ajet/ajet27/lai.html.

22. Mangin, J. P. L., Bourgault, N., León, J. A. M., \& Guerrero, M. M. (2012). Testing control, innovation and enjoy as external variables to the Technology Acceptance Model in a North American French banking environment. Journal of International business research, 5(2), 13-26. Retrieved from: http://ccsenet.org/journal/index.php/ibr/article/view/14579/9942.

23. Makarem, S. C., Mudambi, S. M., \& Podoshen, J. S. (2009). Satisfaction in technology-enabled service Encounters. Journal of Services Marketing, 23(3), 134-144. Retrieved from: http://www.emeraldinsight.com/journals.htm?articleid=1793205.

24. Marketing Charts. (2013). College Students Own an Average of 7 Tech Devices. Retrieved from: http://www.marketingcharts.com/wp/online/college-students-own-an-average-of-7-tech-devices-30430/.

25. Mazhar, N. (2006). Technology Accepted Model. Retrieved from: http://ezinearticles.com/?TechnologyAcceptance-Model\&id=202354.

26. McLaughlin, P., \& Faulkner, J. (2012). Flexible spaces what students expect from university facilities. Journal of Facilities Management, 10(2), 140-149.

27. Mishra, S. (2010). Open and Distance education: History, Status and conceptual analysis. Retrieved from: http://www.slideshare.net/missan/open-and-distance-learning-history-status-and-trends.

28. Nunnally, J. C. (1978). Psychometric theory. 2nd ed. New York: McGraw-Hill.

29. Oblinger, D., \& Oblinger, J. (2005). Educating the next generation. Carolina: Educause. Retrieved from: https://net.educause.edu/ir/library/pdf/pub7101b.pdf.

30. Park, S. Y. (2009). An Analysis of the Technology Acceptance Model in understanding university students' behavioral intention to use e-Learning. Educational Technology \& Society, 12(3), 150-162. Retrieved from: http://www.ifets.info/journals/12_3/14.pdf.

31. QS Top Universities. (2014). Universities using new technologies. Retrieved from: http://www.topuniversities.com/student-info/choosing-university/universities-using-new-technologies.

32. Re:fuel. (2013). Tech-Savvy College Students Are Gathering Gadgets, Saying Yes to Show Rooming and Rejecting Second-Screening. Retrieved from: http://www.globenewswire.com/newsrelease/2013/06/13/554002/10036312/en/Tech-Savvy-College-Students-Are-Gathering-Gadgets-SayingYes-to-Showrooming-and-Rejecting-Second-Screening.html.

33. Ruhe, V., \& Zumbo, B. D. (2009). Evolution in distance education and e-learning: the unfolding model. New York: The Guilford Press.

34. Sewry, D. A., \& Schlenkrich, L. (2012). Factors for successful use of social networking sites in higher education. South African Computer Journal (SACJ), 49: 12-240. Retrieved from: http://sacj.cs.uct.ac.za/index.php/sacj/article/viewFile/78/56.

35. Sohn, T. (2012). Report: Digital Use Up Among College Students. Retrieved from: http://campustechnology.com/articles/2012/05/24/report-digital-use-up-among-collegestudents.aspx $?=$ CTEL.

36. Venter, P., Van Rensburg, M. J., \& Davis, A. (2012). Drivers of learning management system use in a South African open and distance learning institution. Australasian Journal of Educational Technology, 28(2), 183-198. Retrieved from: http://www.ascilite.org.au/ajet/ajet28/venter.html.

37. Webopedia. Social networking site. (Not dated). Retrieved from: http://www.webopedia.com/TERM/S/social_networking_site.html.

38. Winifred1027. (2013). Evaluate the Role and Benefit of Self-Service Technology to Service Retailers. Retrieved from: http://www.studymode.com/essays/Evaluate-The-Role-And-Benefit-Of-1494685.html. 
39. Wong, K. T., Osman, R., Goh, P. S. C., \& Rahmat. M. K. (2013). Understanding student teachers' behavioural intention to use technology: Technology Acceptance Model (TAM) validation and testing. International Journal of Instruction, 6(1), 89-104. Retrieved from: http://files.eric.ed.gov/fulltext/ED539841.pdf. 